\title{
A Politician's Views on Why We are Not Saving Our World
}

\author{
by
}

The Late Mrs INDIRA GANDHI

Twice Prime Minister of India*

\section{INTRODUCTION}

A s a student I read a book on The Politics on the Unpolitical, by Sir Herbert Read. It rightly came to the conclusion that there is no such being, and that those who consider themselves unpolitical are usually the arch-conservatives resisting change. Yet a word is apt to have the meaning with which you choose to clothe it, and many are the words that started off as noble concepts but have acquired a somewhat disreputable aura. Politics is one of them: some call it the art of the possible.

I was born and brought up in an era when politics meant struggle, service, and sacrifice. One cannot easily shed such ingrained convictions. To me, politics is the recognition of duty - of historical imperatives and the constant endeavour to struggle one's way towards them. We cannot always control events, but we can and should control our responses to them - to search for opportunity in the midst of adversity, and above all not be cowed down or be deflected from one's path.

Who is to blame for the present state of the world? No single country, no single set of people, but Mankind's envy and avarice, which are inevitably accompanied by fear and distrust of the systems which develop vested interests.

\section{OUR OWN TIMES}

Indian mythology is replete with stories of those who grew in learning and power, which bred pride and thoughts of invincibility, or of simply not caring. There was a limit to such pride, and Nemesis $\dagger$ was around the corner. These aspects are celebrated even today as symbols of the victory of good over evil. But are they so far from the truth of our own times?

Every country has its problems and together, step by step, they are pushing us to the brink. Industry and power were built on the exploitation of others. Imperialism, nazism, fascism, racialism, old and new colonialism, are the bringers of misery and the sowers of seeds of conflict. Where there is grabbing rather than sharing, there is sure to be inequality and poverty.

The direction of science and technology has produced industries and styles of living which demand certain raw materials, and which pollute the atmosphere, causing health hazards. Lack of responsibility and of due concern has encouraged crime and violence, and has polluted minds. So, people think not of what is good or better but of their vested interests in maintaining the status quo (at least when it is not unattractive to them) and in advancing in that same direction. This has brought attitudes of confrontation which are fanned by, and at the same time themselves encourage, the growth of tension and the production and spread of armaments. Consumer societies of the affluent peoples use more and more of the world's resources, thus widening the gap between the rich and the poor countries and also within countries.

\section{ON From STOCKHOLM}

Ten years ago I said in Stockholm: ‘ Life is one and the world is one... The population explosion, poverty, ignorance, and disease, the pollution of our surroundings, the stockpiling of nuclear weapons and [of] biological and chemical agents of destruction, are all parts of a vicious circle. Each is important and urgent, but dealing with them one by one would be wasted effort... While each country must deal with that aspect of the problem which is most relevant to it, it is obvious that all countries must unite in an overall endeavour.'

Since then the poor have become more acutely aware of, and impatient with, their poverty. Environmentconsciousness has become more widespread, but anti-conservationists have also increased their propaganda and pressure. Some free-marketeers view the concern for 'ecology' as a conspiracy of radicals to interfere with prosperity and progress, while in developing countries it is described as a whim of foreign capitalists who wish to thwart our development. In my own country, development projects become emotional and political issues, and there is resistance even to give ear to the case for conservation. This ignores the permanent harm, caused by deforestation and pollution, to the economy and to the people.

There is no conflict between economic development and environmental conservation, but reconciling the two does need greater effort, more attention to detail, and a heavier financial burden, than is commonly undertaken nowadays. Power projects, irrigation dams, paper mills, coal mines, and sugar factories, are planned to make use of regional resources and to provide employment and incomes, which are economically important commodities that tend to be in short supply.

\footnotetext{
* Prepared in 1982 when the Author was temporarily out of office - for our intended Third International Conference on Environmental Future which was subsequently abandoned owing to pirating of its plan, whereupon the entire programme had to be changed. - Ed.

$\dagger$ The Goddess of Retribution. - Ed.

$\ddagger$ At the United Nations Conference on the Human Environment, which took place during 8-16 June 1972, and at which that address by the Author we recall was one of the most memorable. - Ed.
} 
AdVANCED, DeVEloping, AND Underdeveloped, COUNTRIES

It is well-known that development is more costly for countries which are developing today than it was for those which had their industrial revolution a century or two ago. The latter exploited workers - especially women and children - concentrating on immediate benefit and profit. Ideas of humane treatment and equality followed the industrial revolution, surfacing when the industrialized countries were in a better position than formerly to meet the demands of workers.

We, the developing, are asked to - and indeed we ourselves do - think of the future. But it is strange that this counsel often comes from those who 'had it easy', and who forget that we have started at the other end. First came our political revolution - the consciousness of rights and privileges - before we could possibly have the wherewithal to do much about them. Many developing countries do not enjoy the advantages that the advanced had: vast resources (their own and those of their colonies), small populations, ready overseas markets, capital, comparative lack of mass political awakening, and the absence of international invigilation. Developing countries, on the other hand, face a combination of large populations, limited resources, even more restricted capital, and mounting expectations and demands.

\section{THE CASE OF INDIA}

We do not necessarily imitate the models for growth of industrialized countries. A country of India's size must try to be self-reliant. So whatever may be our model, factories and dams have to be built and mines and canals dug as developed countries have done in the past. Hungry and exploding populations must be fed. So Government must bring more and more land under the plough, ensure irrigation, and enrich the soil with chemical fertilizers. Traditionally underemployed people need fuller and better employment. If they go to schools and colleges, read newspapers, or own radio and television sets, they are lured by the glitter of the affluent countries. The path of development is an endless one: as one demand is met, others arise. It means constant change, and continuous disturbance of existing patterns. If conservation is projected as maintaining the status quo, it cannot command the people's support when they aspire to advance.

In the last century, the British built railways in India without due consideration of the nature of drainage. It took only two decades for the consequences to be felt - especially in Bihar, where large tracts became barren, and others subject to frequent floods. The canal systems, built in the earlier part of this century, have rendered vast stretches waterlogged or saline. During the Second World War, extensive areas of forest in the Himalaya and in our Northeastern and southern mountains were felled to help the war effort.

The era of planned development, which began in 1951, and the devolution of power to village councils, though good in themselves, have seen further reduction of the area under forests. The growth of industry and even agricultural improvements - in fact all solutions - seem to throw up some unexpected problems. We are fast using up the stored resources of the past, in the mistaken belief that the present can be benefited by sacrificing the future.

\section{DEVELOPMENT WITH CONSERVATION}

Development can neither be disowned nor stopped. Nor is it inconsistent with conservation. Awareness of the interconnection of social, economic, and technological, forces is now sufficiently evolved to reconcile development and conservation. But that still leaves out the element of additional cost. Due consideration of the ecological factor makes development more expensive, but at least it will make it more prudent. This is the price which we pay because, for reasons beyond our control, we have been unable to industrialize earlier.

Planned development recognizes our obligations to posterity. In a democratic set-up it implies a stupendous effort at educating the people. Yet often enough, it is the people who educate the administrators! An example is the Chipko movement in our State of Uttar Pradesh, where men, women, and childern, in a sub-Himalayan forest area, physically clung to trees to prevent timber contractors from felling them.* When a hydroelectric project was planned in our southern State of Kerala, in the primeval rain-forest of what is known as 'Silent Valley', scientists voiced their apprehensions ${ }^{\dagger}$ and we were able, though with some difficulty, to persuade the would-be beneficiaries that along with the economic cost-benefit calculations, we should also have a new environmental assessment.

In many, though not all, cases, we have an idea of what is needed to help Nature to keep or restore its equilibrium. In some instances, such as attempts to control insects, this knowledge has come the hard way. But disappearing forests have had predictable consequences -- depletion in rainfall, higher temperatures, loss of land to the desert sands, flash-floods, etc. National and regional leaders must exert an iron political will to ensure that forest resources are used in a planned and wise manner, with adequate replenishment of the

* See Gopa Joshi's account of 'Chipko: A Means of Environmental Conservation' (Environmental Conservation, 8(1), pp. 3-4, fig., 1981) and Richard St Barbe Baker's 'The Story of the First Chipko-hug People (Ibid. 8(3), pp. 226-7, 1981). — Ed.

' See, for example, Dr G.M. Oza's 'Save Silent Valley as a World Heritage Site?' (Environmental Conservation, 8(1), p. 52, 1981), The Sierra Club's International Earthcare Center's 'Silent Valley to be Saved?' (Ibid. 9(1), p. 56, 1982), Professor P.S. Ramakrishnan's 'The Need to Conserve Silent Valley and Tropical Rain-forests in India' (Ibid. 11(2), pp. 170-1, 2 figs, 1984), and Professor J.S. Singh, Dr S.P. Singh, Dr A.K. Saxena \& Dr Y.S. Rawat's 'India's Silent Valley and Its Threatened Rain-forest Ecosystems' (Ibid. 11(3), pp. 223-33, 12 figs and 4 tables, 1984). - Ed. 
vegetation consumed. As in every other commercial activity, there are bound to be people whose economic interest will override reason and every argument for conservation.

There are other complexities. In some parts of India the depletion of forests is caused by tribes which have precious little to survive on. They just do not have the surplus necessary for investment of capital and labour, and need substantial help if they are to keep healthy forests.

\section{ADVANCES FOR DEVELOPMENT}

In India now no project can be approved without studying its environmental implications. We have established a Department of Environment. In fact a little earlier, in 1976, we even amended our Constitution to enshrine our commitment to preserve our natural heritage, declaring 'The State shall endeavour to protect and improve the environment and to safeguard the forests and wild life of the country.' The chapter on Fundamental Duties calls on citizens to 'protect and improve the natural environment including forests, lakes, rivers, and wild life, and to have compassion for living creatures.'

Technological progress converts one-time luxuries into seemingly indispensable necessities. No nation, however Spartan, can now avoid television and an international airline. Our need may be for employmentgenerating technology; but if the advanced nations introduce sophisticated and more and more efficient laboursaving techniques, the pressure on us grows too - especially for reasons of export-competitiveness. Nor can developing countries stick to less-advanced technology. 'Appropriate technology' may amount to acceptance of a perpetuation of disparities, that certain nations will always 'sit below the salt'.

Developing countries need greater research effort to help their endeavours to conserve their environment. India fortunately has a large-enough scientific community to carry out such investigations, but many other nations may not have. International scientific organizations should undertake research projects in a more systematic and, may I say, disinterested, manner than is now done - in reforestation, energy plantations, soil conservation, fertility control, public sanitation, etc., with particular emphasis on cost reduction. The terms of the sale of technological equipment should be such as to encourage conservation. For example, if a developing country buys a coal-based thermal power-unit, it should be given a rebate rather than be asked to pay more for the fitting of smoke-reduction gear.

\section{BRINKMANSHIP OF AFFLUENCE}

The affluent countries are driving along the narrow road on the rim of the cliff. The slightest misjudgment might take them over the precipice and jeopardize future generations. They set the pace; but we, the developing countries, seem to get most of the blame, though increasing awareness of the issues involved is helping us all to some extent. By sharing knowledge, the technologically better-endowed can help to create a more egalitarian world, making it easier for us all to cooperate to solve problems.

The levels of consumption in the developing world are still relatively low, and do not pose an overwhelming threat to the environment; however, if we cannot control our populations, there will be greater trouble ahead. The developed world consumes exhaustible natural resources and energy many times more rapidly than we do. They have luxuries that were undreamt of before, but also growing stress. Surely the anxiety and uncertainty of affluent societies have shown that contentment is unrelated to the level of the possession of goods when once elementary human needs are fulfilled. Those who expect the countries of Africa, Asia, and Latin America, to curb the rates of growth of population for their own good, must make a similar appeal to affluent countries to cut down their consumption levels. Political leaders of developing countries may be able to do the first, but will those of affluent countries be able to do the second?

Poverty is polluting - so is unchecked industrialization and, above all, war which now threatens the use of nuclear, chemical, and biological, weapons.

\section{INTERCONNECTED ISSUES OF OUR ONE WORLD}

Now as never before, no matter what their profession or interest, people cannot remain neutral as regards peace, poverty, and pollution. These issues are interconnected. We live in one world, the only world as yet discovered to be habitable by Humankind*. But in language, thought, and deed, we fragment it and build barriers of race, of religion, of colour, and, above all, of class or economic status. We talk of North and South, of West and East, and of the 'Four Worlds'. Aren't all of them part of the same; aren't all countries interdependent? Basically, problems are indivisible. We must learn to see the world as one whole, and all problems as various aspects of the same crisis of civilization which afflicts all Humankind. Solutions will be neither satisfactory nor enduring if we concern ourselves, as individuals or as governments, with only a particular problem or with short-term concerns.

Living on the brink, as it were, is perilous. It is also a challenge to Man's mind, his heart, and his vision. Human beings have proved their capacity to meet dangers and challenges — their ability to survive. Will these fail us now?

\footnotetext{
* Or, so far as we yet know, supporting life of any form. - Ed.
} 
Professor Polunin asks why politicians are not saving the world. The responsibility to mould the future and to use our increasing knowledge with wisdom and to good purpose lies not only with politicians but also widely with scientists and technologists, with industrialists and organized labour, with journalists, parents, and teachers - in short, with all citizens. Apart from their own positions, theirs are the voices and votes which most influence politicians.

The danger as I see it is not outside but within ourselves and the mores that we set. My own reply to the question is that, in India, we are bending all our energies to safeguard the future, again and again drawing attention to crucial points in public and private pronouncements and in our national and foreign policies which are designed to diminish disparities within our country and between countries, to reduce tensions which might lead to confrontation and conflict, and to match hostility with understanding and friendship. Our aim is not merely material advancement, necessary though it is, but also to enable our people to develop their own inner resources to full capacity, and to rise to greater and greater heights of consciousness.

\section{A Memorial to Ryoichi Sasakawa (1899-1995)}

$\mathrm{M}$ r Ryoichi Sasakawa, Chairman of The Nippon Foundation (formerly known as the Sasakawa Foundation), passed away on 18 July 1995 . He was, as reflecting the vitality and enthusiasm which he poured into his work right up to his final months, 96 years 'young' (Fig. 1).

It was Ryoichi Sasakawa's cherished creed that 'The world is one family; all Mankind are brothers and sisters'. For the human family to live in peace and harmony, he was convinced that it would first be necessary to alleviate human suffering - particularly that caused by disease, hunger, and warfare. To put his beliefs into practice, he initiated the establishment of Japan's first large-scale non-profit philanthropic organization, the Japan Shipbuilding Industry Foundation (later called the Sasakawa Foundation), and built a revenuegenerating system through motorboat racing to finance its widereaching assistance programmes. Through these programmes he made major contributions to the complete eradication of smallpox and to the campaigns against other devastating diseases such as leprosy and AIDS. He was not only quick to offer emergency aid when famine or natural disasters struck, but also implemented farsighted projects to increase staple food production in such regions as sub-Saharan Africa. He, moreover, steadfastly gave his support to the peace-fostering efforts of the United Nations and other international organizations.*

All of Sasakawa's philanthropic endeavors notwithstanding, it was perhaps the Ryoichi Sasakawa Young Leaders Fellowship Fund (SYLFF), which truly transcends national borders and ethnic, religious, and ideological, barriers in its effort to help foster tomorrow's generations of able leaders, that is in the fullest sense a testament to his personal commitment to bring all the world together as 'one family of brothers and sisters'. This steadfast urge, which is central to Kyoichi Sasakawa's unwavering creed, will remain our guiding beacon as we continue to develop the SYLFF programme and other human-resource development programmes in the years ahead.

\section{Communicated by AKINORI SUGAI Department of International Affairs The Nippon Foundation Senpaku Shinko Building 1-15-16 Toranonion Minato-Ku Tokyo 105, Japan.}

\footnotetext{
* Including some of our very small Foundation's, such as our International Conferences on Environmental Future when our personal share of an early International Sasakawa Environment Prize covered our remaining debts for one of them, and a generous donation on behalf of our World Who Is Who and Does What in Environment \& Conservation enabled us to push on with its preparation so that the first edition is now in press and due for publication through Earthscan, London, this year. - Ed.
} 